\title{
On the Problem of Shaping Teaching and Research Skills of Mathematics Students
}

\author{
Golodiuk Larisa* \\ Municipal Institution, Kirovograd Regional IN-Service Teacher Training Institute after Vasyl Sukhomlynsky, Kirovograd, UK Ukraine \\ *Corresponding author: laragolodiuk@gmail.com
}

Received September 18, 2014; Revised October 24, 2014; Accepted December 14, 2014

\begin{abstract}
Social demand for educational services currently requires disclosure and capacity development of each individual, formation of desire for self-improvement, self-determination and creation of conditions for selffulfillment in different types of teaching and learning activities, including teaching and research activities. Singling out teaching and research activity among other types of teaching and cognitive activities in the article and emphasizing its systemic and systematic organization is significant considering that the delineated area of activity is seen, on the one hand, as one of the most effective means of personal development, on the other, as a method aimed at the development of the students' teaching and research skills. The suggested theoretical rationale and guidelines allow a teacher to realize these approaches practically in the educational process of teaching mathematics.
\end{abstract}

Keywords: activities, research activities, teaching and research activities, teaching and research skills, teaching and research tasks

Cite This Article: Golodiuk Larisa, "On the Problem of Shaping Teaching and Research Skills of Mathematics Students." American Journal of Educational Research, vol. 2, no. 12B (2014): 41-45. doi: 10.12691/education-2-12B-8.

\section{Introduction}

The global socio-economic changes in our society identified the need for creative, active, innovative thinking people who can solve set problems in different ways and formulate new promising taskson the basis of critical analysis of the situation. Life requires from school to train a graduate who is able to adapt to changing conditions, sociable and competitive. Today scientists agree that every person has a huge amount of features that are stored in this person as abilities. Public school usually faces the problem of identifying and developing abilities of a student. Considering the system of work with students, we stress the importance of organization of the educational process of work with all students to maximize the development of their skills, cognitive and creative abilities. As a result of changes in the current development of mathematics education we can observe a decrease in the overall level of mathematical preparation of students, particularly, low is the quality of knowledge of geometry, which is necessary to understand many phenomena and processes occurring in the world. This indicates a need to find new approaches and appropriate ways of developing content, techniques, forms and methods of teaching.

In view of the above, we identify relevant issue of teaching mathematics - amending methodological system of teaching maths, and base of bias of priority emphasis, firstly, from student's activity to teacher's activity, and secondly, from behavioral training, which provides the formation of ability to acquire knowledge independently, optimally and flexibly use them in the process of life, acquire the skills of creative style of activity, the implementation of autonomy in decision-making, etc., to the dominant cognitive-reproductive. Such retrogressive replacement is unacceptable for a modern style of teaching because, firstly, it makes students passive "consumers" of the finished product, and secondly, the teacher is perceived by pupils as a single informant of social experience.

Analyzing innovative teaching, it should be noted that the production of new knowledge, creation of new technologies, methods and systems for communications, globalization of social relations are constantly updating requirements for the process and result of interaction between the teacher and students, followed by which the last masters all components of the content of training, developing and educating.

\subsection{Distinguishing the Research Range of Problems (Analysis)}

To define the innovative trajectory of methodological system renewal of teaching mathematics, we have organized and carried out a survey of teachers. The questions of the survey allowed us to determine the level of understanding of an actual problem in the formation of teaching and research skills of students in learning mathematics. Let us discuss some questions where the answers require scientific theoretical and practical rationale.

Question 1. "What activities with students of secondary school can you name teaching and research activities, to 
your point of view?". The respondents gave different formulations (e.g. Fig. 1). It is obvious that there is identification of the concept of "teaching and research activities" with the term "activities related to solving the problematic learning situations." Obviously, this fact requires a theoretical explanation and justification, because the teachers do not understand the conceptual apparatus of innovation that leads to disruption of technology of its use.

Possible answers: a) activities related to solving the problematic learning situations; b) project activities; c) search activities; d) the activity involves the use of information and communication technologies; e) it is difficult to determine; f) there is no answer.

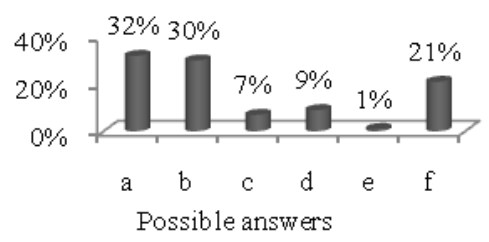

Figure 1. Respondents' answers regarding the definition of "teaching and research activities"

Question 2. "How do you understand the content of the phrase "teaching and research skills of students with mathematics"?" For most teachers this issue turned out to be difficult, that is why $60 \%$ of respondents did not formulate a response (e.g. Fig. 2).

Possible answers: a) skills, that are formed in the process of solving the problematic learning situations; b) skills that are formed in the course of the project; c) skill, which are formed in the process of searching for information; d) there is no answer.

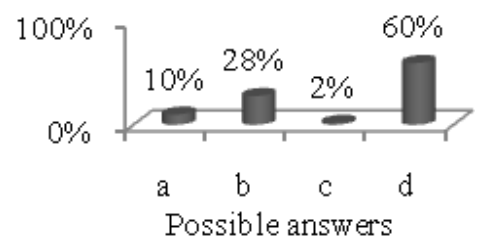

Figure 2. Respondents' answers regarding the understanding the concept "teaching and research ability of students in mathematics"

Question 3. "Can undersigned skills or some of these skills be considered the components of teaching and research skills? Highlight an entry if you consider the skills to the list of training and research skills in mathematics: a) social and interactive skills; b) intellectual and creative skills; c) perceptual and informational skills; d) reflective and analytical skills; e) organizational and adaptational skills" (e.g. Figure 3).

Possible answers: a) no component is selected; b) one component; c) two components; d) three components; e) four components; f) all components.

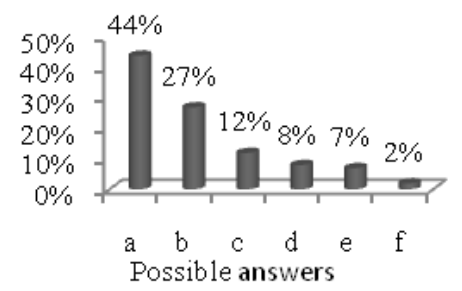

Figure 3. Respondents' answers regarding determination of the components of teaching and research skills
Question 4. "What types of activities of students can be a part of teaching and research activities and facilitate the process of formation of teaching and research skills in adolescent children? In the chosen list underline those activities that you prefer in your work" (e.g. Figure 4).

Possible answers: a) organization of students' work in a training project; b) implementation of design tasks; c) solving the problematic learning situations; d) preparation of informational reports; e) solving the problems of an application content; f) there is no answer.

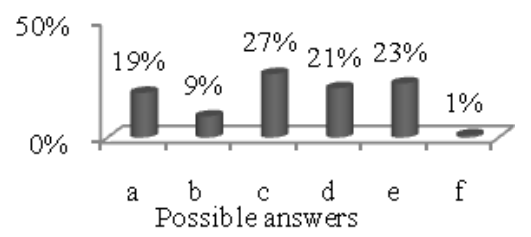

Figure 4. Types of activities that are a priority for teachers in teaching students

Given the results of the survey there is a need for a scientific explanation of basic concepts of the studied problem.

\section{Theoretical Aspect of Teaching and Research Activities of Students (Theory)}

Theory of activity is seen as a system of methodological and theoretical principles of study of mental phenomena. The main object of study is the activity. This approach is examined on two levels: the principle of unity of consciousness and activity (L. Rubinstein [14]) and the problem of common structure of external and internal activities (O. Leontiev [11]).

In his writings, L. Rubinstein considers the activity as a set of actions aimed at achieving the objectives. According to L. Rubinstein, the main features of the activity are such features: sociality (activity is held only by a subject of activity); activity as the interaction of subject and object is meaningful, substantive; activity is always creative and independent. Activity is determined by its object not directly, but only indirectly through its internal specific patterns (due to goal, motivation, etc.). This is a partial manifestation of the general principle of determinism: the external forces act only through the internal conditions of to whom or to what these external influences are indicated. From these perspectives a theory of thinking is created as an activity and as a process [14].

According to O. Leontiev theory, the person is described only by those mental processes and features that facilitate the implementation of the person's activities. The hierarchy of activities forms the core of the personality. The main characteristic of the individual is self-awareness, that is the awareness of a person himself/ herself in the system of social relations. Each age period of a personal development, according to the theory of activity, corresponds to a certain type of activity that takes a leading role in the formation of new mental processes and traits of the personality.

G. Shchukina considers activity as a major form of manifestation of human activity, human's social purpose. The essence of human activity is to transform reality, the active influence of the individual in the objective world. 
The scientist identifies the following main features of a common phenomenon of activities:

1) goal-setting (transformation of general purpose into specific tasks);

2) transformative in nature (activities with the prospect of improving the environment, transformation of the world);

3) objectivity (expressed its objective material basis, its relation to the objective world);

4) deliberate nature (reveals its subject, which is found in goal-setting, in forecasting activities, in promising aspirations) [16].

So, we can say that not certain properties determine the feature of human activity, but their relationship makes the unity and integrity of any activity and its variability. During activity there is not only child's development of an objective world, but also the formation of attitude to it, to a place in this world, to society, to people with whom the child is learning.

The development of a problem of leadership activities became a fundamental contribution of O. Leontiev to the development of the child and age psychology. The scientist has not only described the change in leadership activities in the development of the child, but also initiated the study of the mechanisms of these changes, a transition of one leadership activity to another. Let's note that the leading activity (by O. Leontiev) is an activity that has three characteristics:

1) activities, in the form of which other new types of activities occur and within which they differentiate;

2) activities where mental processes (thinking, perception, memory, etc.)are formed or develop;

3) activity, which determines the basic psychological personality changes in this period of development.

D. Elkonin believes that as a leading activity in adolescence is communication based on different types of socially useful activity [2].

Recently the issues related to the specification of students' activity have been discussing in the literature, in particular, a research activity stands out as one of the types.

According to M.Kniazian, the research activity is called one of the type of students' creative activity, which is characterized by several features:

1. Research activities are related to students' settlement of creative tasks.

2. It is necessarily that research activities have to take place under the supervision of a specialist.

3. The main is to obtain new knowledge. The task should be feasible for students.

4. Research activities can engage all students: those who have a high level of training and those who have an average level [9].

In this description the features are listed very clearly that you can arrange them in a linear chain for cause-andeffect relations: research activity - a kind of creative activity $\rightarrow$ solving creative problems | teacher-led | to acquire new knowledge |students of high and average levels.

Another controversy is the generalization that in the process of research activities students can perform only creative tasks. Take into account the opinion of L. Shelestova who defines that "a creative task is a task during which the student creates a creative product" [[7], p. 35], the organization of the students' research activities is limited by the content of the tasks that performed in the study of mathematics and the level of the students' achievements.

More comprehensive is the definition of "research activities" submitted S. Serova and N. Fomina, including "Research activities are cognitive activities aimed at developing new knowledge about objects and processes, deepening gained knowledge about the subject, the realization of their own desires and capabilities, the satisfaction of interests, disclosure of instincts and abilities of each child. This activity involves obtaining by each participant a specific result in a set of knowledge and skills ... " [[15], p. 27-28].

We agree with the authors who distinguish the research activity as a component of cognitive activity that is directed on the formation of new and deepen existing knowledge through interest and intrinsic motivation of students to the formation of knowledge and skills.

Without dwelling on the analysis of the other options' nature of definitions of a notion "the research activity" and taking into consideration its multidimensional nature, which became the basis for the emergence of new scientific studies, particularly in the sphere of teaching and research (S. Korshunov, N. Nedodatko, I. Kravtsov), search (B. Skomorovskyi, V. Redina), scientific and research (G. Tsehmistrova, O. Anisimova, L. Shevchenko) work, let's single out for further disclosure of the concept of "teaching and research activities".

According to a definition given by O. Obukhov, teaching and research activity of students is a creative process of common activities of the two entities (a teacher and a student) to find the unknown, in the course of which the transmission between cultural values is carried out, which results in the formation of ideology [13]. Describing the teaching and research activities, he emphasizes the basic function: the desire of students to the knowledge of the world, themselves, and themselves in this world. We believe that the purpose of teaching and research activities of students is to provide a focused personal development, acquisition of research skills, mastery of knowledge that are perceived as new and personally meaningful only in relation to specific individual. The object of these activities can be an educational and research objective, which in its essence is informative and oriented to the "zone of proximal development" of the child. Teacher's training of the formation of the students' teaching and research skills is preceded by a successful, effective implementation of teaching and research activity of students.

In organization of scientific and research activities of students we should observe several principles [12]:

- students' research activities are close to the scientific and research activities, its beginning and has often continued in further scientific activities;

- a content of the study must be combined with an educational purpose, general public needs and issues of today;

- scientific research is a continuous process, it can not be run in a few days;

- scientific and research activity is always a controlled process.

Such work of students must meet the scientific methods of knowledge, enhance the content of their education and improve the training to future activities. 


\section{Methodological Aspect of Teaching and research Activities of Students (Methodology)}

In order the work with students was not episodic, but consisted in a certain system, the teacher should identify the main challenges and areas of teaching and research activities of students based on their individual characteristics and qualities. In contrast to the stereotypical traditional teaching, teaching with the organization of teaching and research activities is characterized by feasibility of individualized, differentiated, problem-based, integrated, intersubject approaches to modeling the learning process and is carried towards the creation of conditions for effective implementation of teaching and research tasks in school-time and extracurricular time.

In the process of carrying out teaching and research assignments the students form teaching and research skills, such as: intellectual and creative (skills that ensure efficiency implementation of abstract thought of comparisons, analysis, synthesis, generalization, classification and provide effective mental activity); social-interactive (skills, which are based on actions aimed at establishing and maintaining effective interaction between participants of activity); perceptual-informational (skills, supported by the actions of active perception, memorizing, preservation, restoration and structuring of information; they are found in the implementation of an effective process of perception of information and operating with its contents); organizational and adaptational (skills that provide a productive entry of a child into informational and educational environment, performed by an independent action planning activities in accordance with its objective, the choice of methods to achieve a goal and of the necessary means of determining the sequence of actions in the structure of activity); reflexive and analytical (skills, implemented through actions as a process of introspection to obtain a certain result, and self-regulation as a process of self-formulation of the goal of activities and implementation of its realization).

Teaching and research tasks allow us to: develop learning motivation; stimulate mechanisms of student's orientation; provide independent targeting of future training activities; form general and special students' skills for learning; enhance moral and volitional and physical quality of teaching and cognitive goals of the student to achieve results; maintain a working capacity of the child; provide a self-assessment of activities; create the conditions for implementation of the highest personal functions.

We selected components of teaching and research tasks (tasks for compiling classificational and integrated schemes, tables; tasks for updating methods or ways of solving, task for selection of generalized algorithm, technique or method of solving; tasks for setting properties of shapes; tasks for research properties of geometric configurations which are based on different mathematical descriptions of real processes and situations; tasks for the development of algorithmic and heuristic advice; tasks for modeling; tasks for summarizing the conclusions that can be used to solve personally meaningful problems), based on the formation of mathematical subject competence of secondary school pupils, in a clear systematic sequence of implementation it allows you to create teaching and research skills of students.

In the selection of the components of teaching and research tasks aimed at forming and development of teaching and research skills of students, it is advisable to adhere to the following sequence of operation (Table 1).

Table 1. Technological aspects of formation of teaching and research skills of students through orderly system of tasks

\begin{tabular}{|c|c|c|c|}
\hline \# & The purpose of the organization of students & Activities of students & Technological comment for a teacher \\
\hline 1. & $\begin{array}{l}\text { Determine the level of formed educational } \\
\text { experience of students of mathematical } \\
\text { concepts that will be studied according to the } \\
\text { topic of the next lesson. }\end{array}$ & $\begin{array}{l}\text { Formulation of objectives and } \\
\text { hypotheses of teaching and research } \\
\text { tasks. }\end{array}$ & $\begin{array}{l}\text { A frontal survey is carried out. The responses are } \\
\text { summarized. The misconceptions are identified. The } \\
\text { stated purpose and the hypothesis of teaching and } \\
\text { research tasks are adjusted. }\end{array}$ \\
\hline 2. & $\begin{array}{c}\text { Form the students' skills in planning, working } \\
\text { out the stages of the teaching and research } \\
\text { tasks. }\end{array}$ & $\begin{array}{l}\text { Independent reading and understanding } \\
\text { the stages of implementation of } \\
\text { teaching and research tasks. }\end{array}$ & $\begin{array}{l}\text { Attention is paid to the sequence of stages of } \\
\text { implementation of teaching and research tasks. }\end{array}$ \\
\hline 3. & $\begin{array}{l}\text { Form students' attitudes towards mathematics } \\
\text { as a tool for modeling and study of the world, } \\
\text { discussing examples from the environment, } \\
\text { which can be correlated with the geometric } \\
\text { concepts under study. }\end{array}$ & $\begin{array}{l}\text { Students independently analyze images } \\
\text { on the drawings. They summarize } \\
\text { information and offer their own } \\
\text { example that will continue series of } \\
\text { drawings, given specified properties and } \\
\text { attributes of the object corresponding } \\
\text { images. }\end{array}$ & $\begin{array}{l}\text { A part of the problem, which concerns the choice of } \\
\text { an example of the environment and its image, } \\
\text { students perform at home as a part of homework. }\end{array}$ \\
\hline 4. & $\begin{array}{l}\text { Motivate the feasibility and importance of } \\
\text { formation of the idea or concept, its role and } \\
\text { place in the mathematical knowledge system. }\end{array}$ & $\begin{array}{l}\text { Students are introduced to the historical } \\
\text { material about the origin of the term or } \\
\text { concept. }\end{array}$ & $\begin{array}{l}\text { Students independently complete the task "Refresh } \\
\text { the meaning of the text entitled" Historical origins of } \\
\text { the term or concept". }\end{array}$ \\
\hline 5. & $\begin{array}{c}\text { Form the ability to argue logically and justify } \\
\text { mathematical statements, apply mathematical } \\
\text { methods in the process of learning and solving } \\
\text { practical problems, use mathematical } \\
\text { knowledge and skills while learning other } \\
\text { subjects. }\end{array}$ & $\begin{array}{l}\text { Students perform tasks by modifying } \\
\text { the shape of teaching activities in } \\
\text { accordance with the type of a task. }\end{array}$ & $\begin{array}{l}\text { The teacher leads students to understand the nature } \\
\text { of the geometric material and gives them an } \\
\text { opportunity to move informing their teaching and } \\
\text { research skills, changing the form of learning } \\
\text { activities of students. } \\
\text { The teacher determines the tasks that students } \\
\text { perform at home and in the classroom. }\end{array}$ \\
\hline 6. & Summarize and organize the material studied. & $\begin{array}{l}\text { Students complete the task } \\
\text { independently, summing up digestible } \\
\text { training information. }\end{array}$ & $\begin{array}{l}\text { The teacher checks the validity of the assignment. } \\
\text { The formulated hypothesis of teaching and research } \\
\text { tasks is checked. }\end{array}$ \\
\hline
\end{tabular}




\section{Results}

Testing of the above theoretical and methodological aspects of the research topic for the organization of teaching and research activities of students while learning mathematics, is based on the general educational institutions of the region within the framework of the innovative educational project "Heyday" on the topic "Creating scientific and methodological principles of formation of teaching and research skills of children" [1]. To realize the objectives of the experimental work teaching and research tasks were specially designed $[3,4,5]$, which at the first stage allowed to reveal the nature of the students and teachers' difficulties related to the organization of teaching and research activities on the formation of teaching and research skills of students while learning mathematics.

Evaluation of the results of the experimental study is based on determining the level of teaching and research skills along with using teaching and research tasks.

The data from diagram (e.g. Figure 5) show the growth dynamthe of formation of teaching and research skills students.

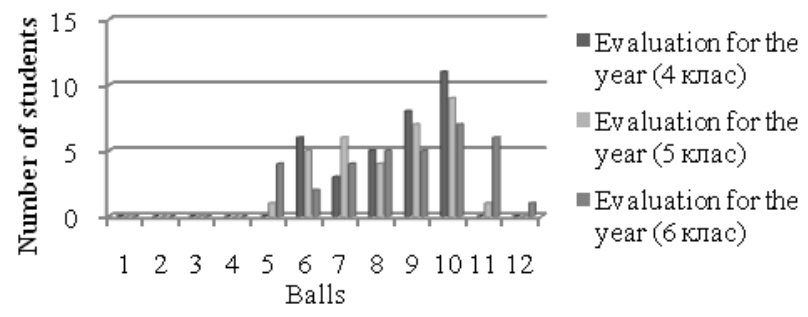

Figure 5. Diagram The level of educational achievements experimental classes

\section{Conclusions}

The first stage of the experiment revealed a number of areas that need to be taken into account in further work, including a clear definition of indicators of forming teaching and research skills through organizing teaching and research school-time activities and extracurricular activities.

We should also pay attention to the activities of students during the implementation of teaching and research objectives with regard to the following levels of manifestation:

- reproductive-imitative (conscious perception of knowledge, their memorizing in the form of direct assimilation of the image of the object under study; the acquisition of certain abilities and skills; reproduction of knowledge and a direct application of abilities, skills);

- partial search-executive (independent solution of the standard learning tasks in the application of guidance materials and algorithms; assimilation of techniques for applying knowledge according to a model, including simple versions of this model);

- creative (self-setting of training objectives, unconventional way to solve them, using the obtained knowledge in unusual situations to solve problems, issues, challenges that are distinguished by global, latent subtext, creative essence, open-type solution, etc.).

Extraction of features of using semantic-symbolic methods in teaching mathematics based on research of N. Tarasenkova [17], and taking into account the level of students' activity will allow to extend component content of teaching and research skills.

The above areas require further research - theoretical and methodological rationale and practical testing and discussion.

\section{References}

[1] Chernetska, T., Organizational and conceptual basis of introduction of innovative educational project "Heyday" on "Capacity-methodical bases developing children's educational and research skills", LLC Praymdruk, Kyiv, 2012.

[2] Elkonin, D.B., "On the problem of periodization of mental development in children”, Questions of psychology, 4, 6-20, 1971.

[3] Golodiuk, L., Guidelines on the formation of teaching and research skills of students in grades 5-6 mathematics lessons, LLC SITIPRINT, Kyiv, 2013.

[4] Golodiuk, L., Perceive, analyze, simulate: a textbook for class 5, LLC SITIPRINT, Kyiv, 2013.

[5] Golodiuk, L., Perceive, analyze, simulate: a textbook for class 6, LLC SITIPRINT, Kyiv, 2013.

[6] Golodiuk, L.S., "Teaching and research activities of students: psychological and pedagogical analysis", Scientific Notes Junior Academy of Sciences of Ukraine, 3, 142-156, 2012.

[7] How to help your child become a creative person / Compiled by L. Shelestova, School world, Kyiv, 2003.

[8] Kirichuk, O.V., Romenets, V.A., Kirilenko, T.S., Manoha, I.P., Piskun, V.M., Tatenko, V.A. and Titarenko, T.M., Psychology, Lybed, Kyiv, 2006.

[9] Kniazian, M.O., "Formation of self-research as a pedagogical problem in the theory and practice of preparing future teachers", Problems of Education, 51, 92-98, 2007.

[10] Kovalenko, V.G., Teslenko, I.F., Problematic approach to teaching mathematics, Soviet school, Kyiv, 1985.

[11] Leontiev A.N., Activity. Consciousness. Personality, Politizdat, Moscow, 1975.

[12] N. Byelich, "Involvement of students in research work", Upbringing. [Online]. Available: http://osvita.ua/school/lessons_summary/upbring/27192/. [Accessed Jul. 02, 2014].

[13] Obukhov, A.S., "Research activities as a possible way to enter the teenager in the cultural space”, School Technology, 5, 26-36, 2001.

[14] Rubinstein, S.L., Fundamentals of General Psychology, Pedagogy, Moscow, 1973.

[15] Serova, S.O., Fomina, N.V., "Way into the world of scientific technology”. School management, 3, 27-29, 2006.

[16] Shchukina, G.I., Role activities in the learning process, Education, Moscow, 1986.

[17] Tarasenkova, N., Using semantic and symbolic tools in teaching mathematics, Echo Plus, Cherkassy, 2002. 